Review Article

\title{
Two Months of COVID- I 9 Pandemic in Nigeria: Distribution and responses of the Nigerian Media
}

\author{
Sylvester Chibueze lzah', ,kiemoye Iniamagha $^{2}$, Ligeiaziba Sylva ${ }^{3}$ \\ ${ }^{1}$ Department of Microbiology, Faculty of Science, Bayelsa Medical University, Yenagoa, Bayelsa, Nigeria. \\ ${ }^{2}$ Centre for English, General and Entrepreneurial Studies, Bayelsa Medical University, Yenagoa, Bayelsa, Nigeria. \\ ${ }^{3}$ Department of Mathematics, Faculty of Science, Bayelsa Medical University, Yenagoa, Bayelsa, Nigeria. \\ DOI: https://doi.org/10.24321/2455.7048.202015
}

\section{I $\quad \mathbf{N} \quad \mathbf{F} \quad \mathbf{O}$}

\section{Corresponding Author:}

Ikiemoye Iniamagha, Centre for English, General and Entrepreneurial Studies, Bayelsa Medical University, Yenagoa, Bayelsa, Nigeria.

E-mail Id:

ikiemoye.iniamagha@yahoo.com

Orcid Id:

https://orcid.org/0000-0003-4136-3783

How to cite this article:

Izah SC, Iniamagha I, Sylva L. Two Months of COVID-19 Pandemic in Nigeria: Distribution and responses of the Nigerian Media. Epidem Int 2020; 5(2): 32-44.

Date of Submission: 2020-05-07

Date of Acceptance: 2020-05-20

\section{$\begin{array}{llllllllllll}\mathbf{A} & \mathbf{B} & \mathbf{S} & \mathbf{T} & \mathbf{R} & \mathbf{A} & \mathbf{C} & \mathbf{T}\end{array}$}

This study reviewed the distribution of and Nigerian Media responses to the COVID-19 pandemic within the first two months (February 27 to April 302020 ) of its outbreak in Nigeria. Using data collected from the websites of the Nigeria Centre for Disease Control, NCDC and Worldometer, and analysed in simple percentages and presented in tables and charts, the study showed that by April 30, 2020, the total confirmed, active, recovered and death cases stood at 1932, 1555, 319 and 58 respectively; an indication of an alarming spread. The distribution of the disease saw Lagos (epicentre of the disease), Kano and FCT collectively accounting for $71.07 \%$ of confirmed cases, $71.45 \%$ of active, $73.67 \%$ of death, and $46.55 \%$ of recovered cases. The initial mode of spread was through contact; however, as of April 30, 2020, 79\% of new cases were through contact and incomplete epidemiological link; an indication of possible community transmission. The Nigerian media responded adequately and aggressively to the outbreak by setting the agenda and providing regular updates of government, private and individual efforts in containing the spread of the disease. By the conclusion of this study, there was the issue of transparency of government and equity in providing and distributing palliatives to cushion the effect of lockdowns, and a confirmation of over 40 healthcare workers testing positive to SARS-CoV-2; thus, challenging the government to intensify efforts in curbing community transmission by ensuring effective contact tracing, testing, isolation and treatment, which were barely successful as of April 30.

Keywords: COVID-19, Epidemiology, Nigeria, Public Health, SARSCoV-2

\section{Introduction}

Within the last few decades, some viral, protozoa and bacteria diseases have killed people in Nigeria. Most Viral Hemorrhagic Fevers (VHFs) belong to Arenaviruses, Filoviruses, Bunyaviruses and Flaviviruses. Specifically, the VHFs of concern in Nigerian are Lassa fever, Ebola, Dengue fever and Yellow fever. Yellow and Dengue fevers belong to Flaviviridae family. Yellow fever cases and deaths have been recorded in Nigeria. Like dengue fever, yellow fever is transmitted by some species of mosquito. In Nigeria, there was no confirmed case between 1996 and 2017, until it was reported in September 2017. Thereafter, other outbreaks were recorded in Nigeria. Cases of dengue fever have been previously reported in northern Nigeria. For Lassa fever, it is caused by a virus that belongs to the family 
of Arenaviridae. Nigeria is one of the countries that the fever is endemic (a localised outbreak affecting a specific population is often referred to as epidemic) in West Africa. In 2018, there were over 600 confirmed cases and over 170 deaths in Nigeria with fatality rate ranging from 3 to $42 \%$. Ebola virus disease, which the causative agent belongs to the Filoviridae family, is another hemorrhagic fever with a fatality rate of $25-90 \%$. Ebola virus disease was first confirmed in Nigeria on July 22, 2014 with a total of 20 cases and 8 deaths; a fatality rate of $42 \%$ and by October $20^{\text {th }}, 2014$, World Health Organization declared Nigeria free from Ebola virus disease. ${ }^{1}$

Protozoan based diseases such as malaria are common in Nigeria. This is because of the presence of the vector (female Anopheles mosquito) in the environment. Studies have indicated that a significant number of Nigerians is at risk of contracting the disease on daily basis. Global burden of malaria frequently occurs in Africa and Nigeria has been referred to as one of the endemic zones of malaria. ${ }^{2,3}$ In 2015, for instance, 88 and $90 \%$ malaria cases and death respectively occurred in Africa; Nigeria accounts for approximately, $25 \%$ of the total global cases.

Several other bacterial diseases such as cholera, tuberculosis, etc. are also prevalent in Nigeria and have been successfully managed. Cholera is caused by Vibrio cholera and characterised by acute diarrhoea. Cholera, particularly, is endemic in Nigeria and is influenced by season (occurring mostly in the wet season). Several outbreaks have been recorded in approximately 20 states in Nigeria.

In the first quarter of 2020, there was a global pandemic (disease that affects a large, heterogeneous population) resulting from a novel coronavirus which is now known as Severe Acute Respiratory Coronavirus 2 (SARS-CoV-2) causing Coronavirus Disease 2 (COVID-19). Information from Worldometer ${ }^{4}$ showed that between late December 2019 and April 13, 2020, the disease had spread to over 210 countries and territories around the world and two international conveyances in the world. As of April 13, 2020, there were 1,936,697 confirmed cases, causing 120,567 deaths (with fatality rate of $6.23 \%$ ) and 458,989 have recovered (recovery rate of $23.70 \%$ ). Furthermore, active cases stood at $1,357,133$ (accounting for $70.07 \%$ of all cases) thus far globally. With regard to the condition of the active cases, $96 \%$ were mild while $4 \%$ were critical. These values have since changed as at April 30, 2020.

On a global scale, during the period of study, the fourteen highest confirmed cases were in United States of America (587,173 cases, $4.03 \%$ fatality rate), Spain (172,541 cases, $10.46 \%$ fatality rate), Italy $(159,516$ cases, $12.83 \%$ fatality rate), France (136,779 cases, $10.94 \%$ fatality rate), Germany (130,072 cases, $2.46 \%$ fatality rate), United Kingdom $(88,621,12.78 \%$ fatality rate), and China $(82,249$ cases,
$4.06 \%$ fatality rate). Others were Iran (74,877 cases, 6.25 $\%$ fatality rate), Turkey (61,049 cases, $2.12 \%$ fatality rate), Belgium $(31,119$ cases $13.36 \%$ fatality rate), Netherlands $(26,551$ cases, $10.63 \%$ fatality rate), Switzerland $(25,807$ cases, $4.48 \%$ fatality rate), Canada $(25,680$ cases, $3.04 \%$ fatality rate) and Brazil (23,723 cases, 5.71\% fatality rate). As at April 13, 2020, 949 new deaths have occurred in 31 countries and territories with over 300 in Spain, 254 in Belgium, 98 in Iran, 60 in Indonesia, 36 in Mexico, 27 in Brazil, 22 in Russia and Philippines, 17 in Switzerland, 16 in Austria and 15 in Romania; with some other 20 countries accounting for the remaining 84 deaths.

Some countries recorded remarkable recoveries from the disease. Countries like China, Germany, Spain, Iran, USA, Italy, France, Switzerland, Canada, Austria, South Korea and Belgium had recovery rates of $95 \%, 52 \%, 39 \%, 64 \%$, $6 \%, 22 \%, 20 \%, 53 \%, 30 \%, 54 \%, 71 \%$ and $22 \%$ respectively. USA, Italy, France, Spain, UK, Germany, Turkey, Netherlands, Iran, Belgium, Brazil, Russia, Canada, Portugal, Switzerland and Ireland are the countries with the highest number of active cases as of April 13, 2020. However, the recovery rates improved tremendously as of April 30, 2020.

The pandemic is one of the disasters that had spread to about 210 countries and territories cutting across Europe, North America, Asia, South America, Africa and Australia/ Oceania within 15 weeks, killing people of all ages. Since the history of man, this was one of the pandemics that had spread to nearly all countries in the world. Fortunately, we can ascertain that the fatality rate is still low compared to other viral hemorrhagic fevers such as Ebola, yellow and Lassa fever that are widespread in some Sub-Sahara African countries.

Disappointingly, Nigeria happened to be one of the countries in Africa badly hit by the disease. As at midnight, April 30, 2020 , there were about 1,555 active cases, 58 deaths and 319 recovered cases across 35 states, including the Federal Capital Territory, Abuja. Just like other parts of the world, several measures were taken to curtail the global pandemic. Therefore, this paper assessed the distribution of the virus and the responses of the Nigerian media for the first two months of its outbreak.

\section{Methodology}

The data were analysed using simple percentages and presented in Tables and charts. For this study, secondary data of Covid-19 patients were collected from the websites of Nigerian Centre for Disease Control (NCDC) $)^{5}$ and Worldometer ${ }^{4}$ for the period spanning February 27, 2020 to April 30, 2020. The information includes all confirmed cases of COVID-19 found and tested in Nigeria, comprising both Nigerians and non-Nigerians in Nigeria only; Nigerians in Diaspora were not captured. The epidemiological data 
includes travel history, contacts, state of residence and geographical zones.

\section{Origin of COVID- 19 and its Introduction in Nigeria}

Coronavirus-like diseases have been around for some time. Some of them have been observed in animals such as Asian leopard cat, giraffe, raccoon dog, antelope, peafowl, bat, among others; while some others occurred in humans. ${ }^{6}$ The three major human coronavirus diseases that cause severe respiratory difficulty were common to Asia. For instance, the 2003 Severe Acute Respiratory Syndrome (SARS) coronavirus originated from China, while the 2012 Middle East Respiratory Syndrome (MERS) coronavirus originated from Saudi Arabia. Suffice you to note that disease outbreaks are often classified based on the geographic spread.

A third novel coronavirus, whose causative agent has not been previously identified in humans before now, emerged from China again, specifically, Wuhan city in Hubei province, in December 2019, killing thousands of people across the globe as of the $30^{\text {th }}$ of April, 2020. The disease was carefully studied and monitored by the World Health Organization, and after about seven weeks, it was officially named as Coronavirus Disease 2019 (COVID-19) on the $11^{\text {th }}$ of February, 2019, and the causative agent identified as Severe Acute Respiratory Syndrome Coronavirus 2 (SARSCoV-2) by the International Committee on Taxonomy of Viruses. ${ }^{7}$ The coronavirus disease 2019 is the widest spread global pandemic of the $21^{\text {st }}$ century.

The origin of COVID-19 has several myths to it. Some think it is a biological weapon (man-made), while others, a natural and possible transmission from animals (precisely, pangolin and bat) to humans after it had mutated. Throughout this study, there was no scientific proof to show that the virus was engineered in the laboratory, even though there is a coronavirus based laboratory in the region of China, where the virus was first identified. Besides, a study by Cheng et al [6] had earlier indicated that there was the need for the world to prepare for the possibility of the emergence and re-emergence of a severe acute respiratory coronavirus-like virus from animals and laboratories in China, possibly due to the habit of eating unusual wildlife. Consequent to their study, it would, therefore, be safe to align with the school of thought that the virus might have spilled from animals and changed its form to become virulent in humans.

Nigeria recorded its first index case through a 44-year old Italian who was diagnosed with the disease on the $27^{\text {th }}$ of February, 2020 at the Infectious Disease Hospital (IDH), Lagos, Nigeria. The index case entered Lagos, Nigeria on February 24, 2020 and moved to the neighbouring state, Ogun, on the $25^{\text {th }}$ of February, 2020 where he presented symptoms of the deadly disease on February 26, 2020, and was further referred to IDH and confirmed positive. Nigeria then became the third country in Africa to have confirmed the disease.

Nigerian government activated its multi-sectoral emergency operation at level 3, spearheaded by the Nigerian Centre for Disease Control, NCDC. Contact tracing of the index case was made particularly in Lagos and Ogun states. On March 8, 2020, by 12 p.m., about 27 people were screened in Ogun, Lagos, FCT, Kano and Edo states. Of these, one new case (a contact of the index case) was confirmed positive, making the total number of people that had contracted the disease to be two in Ogun state. But, the particular case was transferred to IDH, Lagos for treatment.

On March 16, 2020, another new case was confirmed in Lagos (a returnee from the United Kingdom). But then, the contact of the index case from Ogun state had recovered and was discharged. Before long, the virus had spread to Enugu, Kano, Rivers and Yobe states, after the people came down with symptoms of the disease. From then on, there was daily record of new cases, few deaths and the recovery rate, somewhat impressive.

Based on the epidemiological information presented by the NCDC (2020), there are four major provenances of the disease: travel history, contact, unknown source/ no epidemiological link and incomplete epidemiological data as illustrated in Figure 1 and 2. This was presented when there were 4 provenances (Figure 1) spreading from April 9 to April 30, 2020, and 3 provenances (Figure 2) spreading from March 29 to April 8, 2020. From Figure 2, it shows that the disease was common in people with apparent travel history to a COVID-19 endemic region, between March 29 and April 8, 2020. However, by April 15, 2020, the travel history provenance had begun to decrease. Contact with confirmed cases and incomplete epidemiological link began to rise from April 17, 2020 to April 26, 2020. Soon, the latter would become second after the travel history provenance (Figure 1), thereby suggesting community transmission.

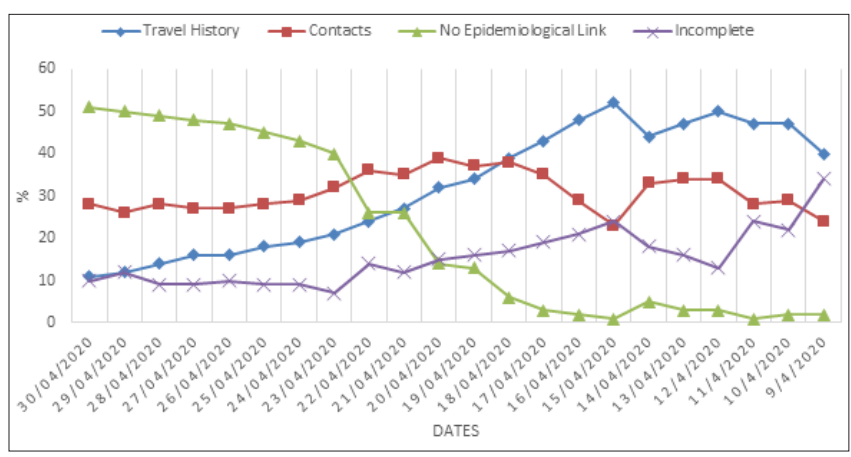

Figure I.Provenance (travel history, Contact, unknown source and incomplete epidemiological link) data of COVID- 19 in Nigeria from 9 April to 30 April 2020. Adapted from $\mathrm{NCDC}^{5}$ 


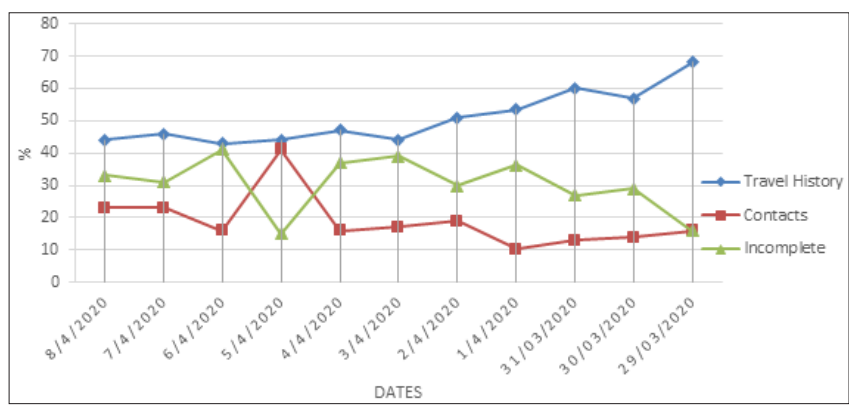

Figure 2.Provenance (travel history, Contact and incomplete epidemiological link) data of

COVID-19 in Nigeria from 29 March to 8 April 2020. Adapted from $\mathrm{NCDC}^{5}$

\section{Distribution of COVID-19 in Nigeria}

Figure 3 and 4 show the distribution of COVID-19 confirmed cases in Nigeria. Between February 27 and April 30, 2020, the confirmed cases of COVID-19 in Nigeria increased from 1 to 1932 in 35 states, including the Federal Capital Territory, Abuja. The affected states include Ogun, Lagos, Ekiti, FCT, Oyo, Edo, Bauchi, Ogun, Rivers, Enugu, Benue, Kaduna,Akwa-lbom, Ondo, Kwara, Delta and Kastina. The others were Niger, Anambra, Kano, Borno, Jigawa, Abia, Adamawa, Plateau, Gombe, Sokoto, Zamfara, Imo, Taraba, Ebonyi, Kebbi, Bayelsa, Yobe and Nasarawa. Kogi and Cross Rivers States had not recorded any case as of April 30, 2020.

The line graph of daily confirmed cases reported by NCDC for the month of March showed an upward trend from midmonth of March with very sharp spikes in the latter part of the month, and presenting an uneven spread. The month of March recorded 20 as the highest number of confirmed cases recorded for a day. The graph also showed that Nigeria was unable to flatten the curve of new cases because, expectedly, some carriers of the virus were asymptomatic during the incubation stage of the disease; thus, they would not have presented themselves for testing. Above all, the data for the month of March showed that most of the confirmed cases had travel history.

In April, the confirmed cases reported by NCDC also showed an upward trend. The plot showed a fairly stable number of new cases in the first half of the month with a sharp upward trend for the remaining days. The data showed that 1 out of 25 patients died from the disease in April. A comparison of the two months (March and April) showed that the disease spread was worse in April with an average of 25.9 new cases daily. In April, new cases did not flatten because of the slow rate of contact tracing, isolation and testing.

Table 1, shows the percentage distribution of confirmed, admission, discharged cases and deaths at April 30, 2020 in Nigeria according to states and region. The values show that Lagos is the leading state of 1932 confirmed cases (50.52\%). This makes Lagos the epicentre of the disease in Nigeria. This is closely followed by Kano and FCT that account for
$11.34 \%$ and $9.21 \%$ of total confirmed cases. At the time, Imo, Plateau, Anambra, Yola and Benue were with 1 case each (accounting for $0.05 \%$ ); 1555 patients were on admission nationwide and Lagos, Kano, FCT, Gombe, Borno and Ogun accounting for $48.62 \%, 13.89 \%, 8.94 \%, 4.89 \%, 3.86 \%$ and $3.02 \%$, respectively. The distribution of the disease saw Lagos, Kano and FCT collectively accounting for $71.07 \%$ of confirmed cases, $71.45 \%$ of active, $73.67 \%$ of death, and $46.55 \%$ of recovered cases. The index case of Anambra state was discharged and no patient on admission. 319 patients were discharged in Lagos (accounting for 62.38\%), FCT, Ogun, Edo, Bauchi, Sokoto, Kaduna, Osun, Oyo, Akwa-lbom, Rivers, Kwara, Delta, Ondo, Ekiti, and Enugu. Within the period of review, 58 people had died after testing positive to the disease with many dying as a result of underlying medical conditions, and some failing to report themselves to their healthcare providers early enough.

Table I.Percentage distribution of confirmed, active, discharged and deaths cases as at $\mathbf{3 0}$ April 2020 in Nigeria according to states and region

\begin{tabular}{|c|c|c|c|c|}
\hline $\begin{array}{c}\text { Affected } \\
\text { states } \\
\text { including } \\
\text { FCT }\end{array}$ & $\begin{array}{c}\text { Laboratory } \\
\text { confirmed } \\
\text { cases, } \%\end{array}$ & $\begin{array}{c}\text { No of } \\
\text { active } \\
\text { cases, \% }\end{array}$ & $\begin{array}{c}\text { No. } \\
\text { disch- } \\
\text { arged, } \\
\%\end{array}$ & $\begin{array}{c}\text { No. of } \\
\text { deaths, } \\
\%\end{array}$ \\
\hline Lagos & 50.52 & 48.62 & 62.38 & 36.21 \\
\hline Kano & 11.34 & 13.89 & 0.00 & 5.17 \\
\hline FCT & 9.21 & 8.94 & 11.29 & 5.17 \\
\hline Gombe & 3.93 & 4.89 & 0.00 & 0.00 \\
\hline Borno & 3.42 & 3.86 & 0.00 & 10.34 \\
\hline Ogun & 2.90 & 3.02 & 2.51 & 1.72 \\
\hline Edo & 2.28 & 1.99 & 3.13 & 5.17 \\
\hline Katsina & 2.07 & 2.44 & 0.00 & 3.45 \\
\hline Bauchi & 1.97 & 2.06 & 1.88 & 0.00 \\
\hline Sokoto & 1.86 & 1.99 & 0.31 & 6.90 \\
\hline Kaduna & 1.81 & 1.80 & 1.88 & 1.72 \\
\hline Osun & 1.76 & 0.84 & 5.64 & 5.17 \\
\hline Oyo & 1.19 & 0.77 & 2.82 & 3.45 \\
\hline Akwa Ibom & 0.83 & 0.26 & 3.13 & 3.45 \\
\hline Rivers & 0.67 & 0.58 & 0.63 & 3.45 \\
\hline Kwara & 0.57 & 0.58 & 0.63 & 0.00 \\
\hline Delta & 0.47 & 0.19 & 1.25 & 3.45 \\
\hline Ondo & 0.47 & 0.39 & 0.94 & 0.00 \\
\hline Taraba & 0.41 & 0.51 & 0.00 & 0.00 \\
\hline Ekiti & 0.41 & 0.32 & 0.63 & 1.72 \\
\hline Jigawa & 0.36 & 0.39 & 0.00 & 1.72 \\
\hline Bayelsa & 0.26 & 0.32 & 0.00 & 0.00 \\
\hline
\end{tabular}




\begin{tabular}{|c|c|c|c|c|}
\hline Zamfara & 0.21 & 0.19 & 0.00 & 1.72 \\
\hline Enugu & 0.16 & 0.06 & 0.63 & 0.00 \\
\hline Nasarawa & 0.16 & 0.19 & 0.00 & 0.00 \\
\hline Niger & 0.10 & 0.13 & 0.00 & 0.00 \\
\hline Abia & 0.10 & 0.13 & 0.00 & 0.00 \\
\hline Adamawa & 0.10 & 0.13 & 0.00 & 0.00 \\
\hline Kebbi & 0.10 & 0.13 & 0.00 & 0.00 \\
\hline Ebonyi & 0.10 & 0.13 & 0.00 & 0.00 \\
\hline Imo & 0.05 & 0.06 & 0.00 & 0.00 \\
\hline Plateau & 0.05 & 0.06 & 0.00 & 0.00 \\
\hline Anambra & 0.05 & 0.00 & 0.31 & 0.00 \\
\hline Benue & 0.05 & 0.06 & 0.00 & 0.00 \\
\hline Yobe & 0.05 & 0.06 & 0.00 & 0.00 \\
\hline & 100 & 100 & 100 & 100 \\
\hline
\end{tabular}

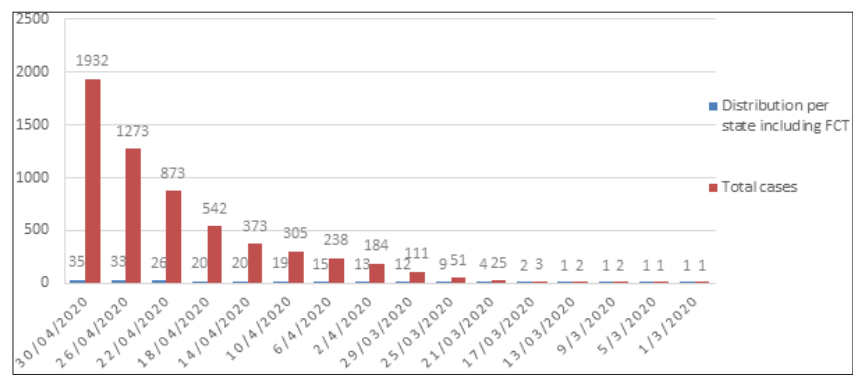

Figure 4.Distribution of COVID- 19 confirmed cases in Nigeria from 27 March to April 302020 at 4 days' interval. Adapted from $\mathrm{NCDC}^{5}$

Table 2, shows the distribution of the COVID-19 status in Nigeria as at April 30, 2020 into geopolitical zones plus the Federal Capital Territory, Abuja. Of the 1932 COVID-19 confirmed cases, the percentage distribution based on the geopolitical zones of North East, North Central + FCT, North West, South West, South South and South East was 9.89\%, $10.14 \%, 17.75 \%, 57.25 \%, 4.50 \%$ and $0.47 \%$, respectively.

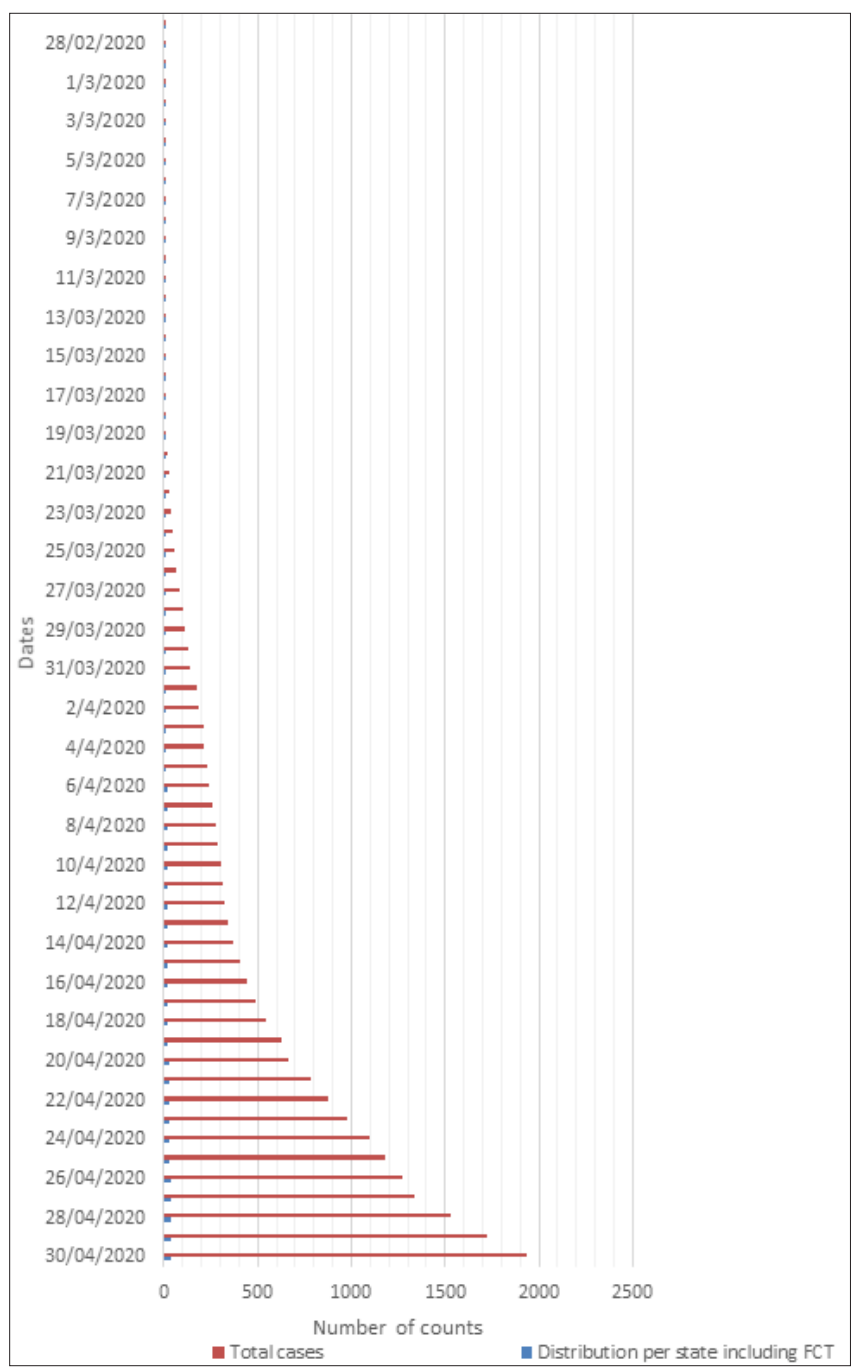

Figure 3.Distribution of COVID- 19 confirmed cases in Nigeria from 27 March to April 302020 Adapted from NCDC 5
The active cases as of the time of this review were 1555 and the percentage distribution based on geopolitical zones was $11.51 \%, 9.97 \%, 20.84 \%, 53.95 \%, 3.34 \%$ and $0.39 \%$ for North East, North Central + FCT, North West, South West, South South and South East, respectively.

In the period of review, 219 patients recovered, and the distribution in percentage into North East, North Central + FCT, North West, South West, South South and South East was $1.88 \%, 11.91 \%, 2.19 \%, 74.92 \%, 8.15 \%$ and $0.94 \%$ respectively.

58 people died and the percentage distribution into the geographical zones of North East, North Central + FCT, North West, South West, South South and South East was $10.34 \%$, $5.17 \%, 20.69 \%, 48.28 \%, 15.52 \%$ and $0.00 \%$, respectively.

Only two states-Cross Rivers in the South-South, and Kogi in North Central had not recorded COVID-19 cases as of April 30, 2020. Overall, the highest number of confirmed, active, recovered and death cases were in the South West and least in South East zones.

\section{Media Responses to COVID-19 outbreak in Nigeria}

It is very pertinent to define or specify the type of media when information dissemination assumes the centre stage of any discourse. This is because there are the traditional media which include the electronic media (radio and television) and print media (newspapers, magazines, books) and the new (social) media, which became prominent as a result of the advent of Information and Communication Technology (ICT). The latter (new media) have become a veritable tool for even the traditional media to improve on the quality of their information dissemination. There is no serious radio, television, newspaper, magazine outfit, today, that does not adopt the new media, powered by ICT to ensure quality output. 
Table 2.Distribution of COVID-I 9 status in Nigeria as at April 30, 2020 according to geopolitical zones including the FCT, Abuja. Adapted from NCDC 5

\begin{tabular}{|c|c|c|c|c|c|c|c|c|c|}
\hline \multirow{2}{*}{ Geo-political zone } & $\begin{array}{c}\text { Number } \\
\text { of states } \\
\text { including FCT }\end{array}$ & \multicolumn{2}{|c|}{$\begin{array}{c}\text { No. of } \\
\text { laboratory } \\
\text { confirmed cases }\end{array}$} & \multicolumn{2}{|c|}{$\begin{array}{c}\text { No. of active } \\
\text { Cases }\end{array}$} & \multicolumn{2}{|c|}{$\begin{array}{c}\text { No. of } \\
\text { discharged cases }\end{array}$} & \multicolumn{2}{|c|}{ No. of Deaths } \\
\cline { 2 - 12 } & & Counts & $\%$ & Counts & $\%$ & Counts & $\%$ & Counts & $\%$ \\
\hline North East & 6 & 191 & 9.89 & 179 & 11.51 & 6 & 1.88 & 6 & 10.34 \\
\hline North Central + FCT & 6 & 196 & 10.14 & 155 & 9.97 & 38 & 11.91 & 3 & 5.17 \\
\hline North West & 7 & 343 & 17.75 & 324 & 20.84 & 7 & 2.19 & 12 & 20.69 \\
\hline South West & 6 & 1106 & 57.25 & 839 & 53.95 & 239 & 74.92 & 28 & 48.28 \\
\hline South South & 5 & 87 & 4.50 & 52 & 3.34 & 26 & 8.15 & 9 & 15.52 \\
\hline South East & 5 & 9 & 0.47 & 6 & 0.39 & 3 & 0.94 & 0 & 0.00 \\
\hline & 35 & 1932 & 100.00 & 1555 & 100.00 & 319 & 100.00 & 58 & 100.00 \\
\hline
\end{tabular}

In fact, as of this moment, physical structures may not be necessary for an individual to begin an information disseminating medium. All that is required are a laptop, and internet connectivity, and one is in the business of communicating news to homogeneous and heterogeneous audiences. The likes of Sahara Reporters and Premium Times in Nigeria are organised new media that operate like the traditional print media, but thrive only on the internet. Even their traditional media counterparts now have online versions, which have further bettered their timeliness in breaking the news.

The new media often referred to as Social Media operate on platforms like Twitter, personal or sponsored news blogs/ websites, Youtube, Facebook, Instagram, Skype, Facetime, etc. Nevertheless, there is this contention whether every information handler using these new media platforms should be subjected to the ethics guiding the traditional media. This is consequent to protests by governments and individuals who feel the new media have now become useful for the propagation of untruth. Should every user of social media be subjected to the ideologies the traditional media thrive on?

The media (traditional) are the middle men in any society as they are regarded as the fourth estate of the realm; where they hold the Executive, Legislature and Judiciary arms of governments accountable to the people. Now, should the new media be seen as part of the fourth estate of the realm? For this paper, the new media would be considered a little place as part of the realm owing to their immense contribution in enhancing information dissemination. Because of the contributions of individuals in contemporary times in information dissemination, they have been referred to as Citizen Journalists-people who have not undergone professional training in journalism and information dissemination, but indirectly practice it.
It should be noted, therefore, that the media (traditional and new media) have a serious duty to inform, educate and entertain their audiences.

This task is hinged on the Social Responsibility Theory of the media which is based on the recommendations designed by the Hutchins commission that was set up in 1947 to fashion out a workable media system that will balance freedom with maintaining societal cohesion. In other words, the media should be available for the representation of all shades of opinion and interest. ${ }^{8}$ Social responsibility theory according to Baran and Davis. ${ }^{9}$ emphasises the need for an independent press that scrutinises other social institutions and provides objective, accurate news reports. The theory calls for the media to be responsible for fostering productive and creative "great communities".

Summarily, Mcquail ${ }^{10}$ highlights the basic principles of the social responsibility theory as:

- Media should accept and fulfill certain obligations to society.

- $\quad$ These obligations are mainly to be met by setting high professional standards of informativeness, truth, accuracy, objectivity and balance.

- The media should avoid whatever might lead to crime violence or civil disorder or give offence to minority groups.

- The media as a whole should be pluralist and reflect the diversity of their society giving access to various points of views and to right of reply.

- Society and the public have a right to expect high standards of performance, and intervention can be justified for public good.

- Journalists and media professionals should be accountable to society as well as employers and the market. 
Notably, Ndimele and Kasarachi ${ }^{8}$ gave an apt summary of Hutchins commission's recommendations by stating that the mass media are expected to:

- Provide a truthful, comprehensive and intelligent account of the day's events in a context which gives them meaning.

- $\quad$ Provide a forum for the exchange of comments and criticism.

- $\quad$ Provide a representative picture of the constituent groups in society.

- Be responsible for the presentation and classification of the goals and values of the society.

- Provide full access to the day's intelligence.

Nonetheless, another media theory happens to be relevant to this discourse; and that is the Development Media Theory. This theory thinks that the media when reporting should always channel their mind towards achieving national development and that the media should be involved in the business of development as a matter of obligation. Daramola ${ }^{11}$ in conceptualising the Development Media Theory notes that the press has "the right to communicate" as well as "the need to use communication to achieve social change and better life".

Remarkably, once again, Mcquail ${ }^{10}$ summarises the components of development media theory thus:

- Media must accept and carry out positive development tasks in line with nationally established policy.

- Freedom of the media should be open to economic priorities and development needs of the society.

- Media should give priority in their content to the national culture and language.

- Media should give priority to news and information gathering and dissemination tasks.

These media theories provide us the leeway to interrogate the responses of the Nigerian media to the outbreak of the new Coronavirus caused by SARS-CoV-2, which was first noticed in December, 2019, when pneumonic symptoms posed fatal consequences to humans in Wuhan, China's Hubei province. The World Health Organisation (WHO) eventually declared it a pandemic as it rapidly spread across the world, and subsequently named it Covid-19.

With the Nigerian government announcing its first case on February 27, 2020, when an Italian national arrived Lagos from his country, Italy-a country badly hit by the pandemic-came down with the virus, and the number of cases increased drastically, in spite of the argument that the cases may have been more than what is being declared by the Nigerian Centre for Disease Control (NCDC), if not for the challenge of inadequate testing; how have the media responded to the outbreak of the new coronavirus pandemic in Nigeria? Have their reportage been with all sense of responsibility, thereby being the true watchdog of the society? Have they communicated "to achieve social change and better life" (ibid), as well as safety from the new coronavirus? Have they carried out "tasks in line with nationally established policy?" (ibid).

\section{How have the Media reportage been?}

It would be appropriate to quickly mention that this paper may not be able to capture in detail all the events that occurred in the thirty-six states of the federation and FCT in the war against COVID-19. It would however, highlight some events that interest this researcher within the period of writing, whereas there were several uncaptured events.

Ever since the first case was recorded, both the traditional and new media have not relented in their reportage. The traditional media have constantly informed their audiences through news, jingles, advertisements, public announcements; and the new (social) media have also been replete with conversations, tweets, video skits and messages of awareness campaign. These have helped a great deal in the war against COVID-19. In fact, the tips of staying safe from the virus have been aggressively broadcast in the media that it would be unfair to say that the media had not done well in their awareness-creation function. There emerged a funny but interesting social media broadcast on how people should stay safe, and must not go without mention in this paper. It goes:

i. Avoid touching "MEN"-Mouth, Eye, Nose, with unclean hands; use hand sanitizers, and wash your hands with soap and water regularly to stay safe and stop the spread of COVID-19.

ii. Fulfill the rights of "WOMEN"-Wash your hands, Obey stay-at-home directives, Move away from crowded places, Exercise regularly, but indoors, No shaking and hugging.

As a matter of fact, the media have been responsive on:

- The response of the government to the outbreak-The Lockdown.

- Compliance-whether or not citizens are adhering to lockdown injunction.

- The issue of government implementing palliatives to cushion the effect of the coronavirus crisis on the poor and vulnerable.

- The reactions of the citizens towards the outbreak.

- The provision of medical kits for health workers who are the frontliners in the war against the virus.

\section{Imposition of Lockdown}

When the first case was recorded in Lagos on the February 27, 2020, and President Muhammadu Buhari didn't address the nation, whereas his contemporaries elsewhere in the world briefed their countrymen on daily basis, it sparked 
anger and a barrage of criticisms from all corners of the country-on the streets, media; people expressed their profound displeasure. However, after one month of the virus in the country, when states like Rivers, Bauchi, Kaduna had recorded cases and Ekiti, Ogun, Lagos (the epicentre of the disease in Nigeria), and Abuja, the Federal Capital Territory had recorded deaths, the President finally addressed the nation on the $29^{\text {th }}$ of March, 2020, requesting the residents of Lagos and Ogun States as well as the Federal Capital Territory to remain at home for fourteen days starting from Monday, March 30, 2020. Even though the President's handlers made excuses for this delay, his speech was not received with rousing applause as many state governors had taken initiatives to protect their citizens.

After the expiration of the fourteen days total lockdown that the President imposed on Lagos and Ogun States in his first address on the March 29, 2020, he announced an extension of the lockdown in paragraph 37 and 38 of his second address on April 13, 2020:

"... Our approach to the virus remains in 2 steps - First, to protect the lives of our fellow Nigerians and residents living here and second, to preserve the livelihoods of workers and business owners. With this in mind and having carefully considered the briefings and Report from the Presidential Task Force and the various options offered, it has become necessary to extend the current restriction of movement in Lagos and Ogun States as well as the FCT for another 14 days effective from 11:59 pm on Monday, 13th of April, 2020. I am therefore once again asking you all to work with Government in this fight...". ${ }^{12}$

After his address, the media did not hesitate to take it up from there (Figure 5) as they opened it up for extensive and exhaustive analysis from different perspectives, with the aim of ascertaining the sincerity of the speech, whether or not it is backed with strong political will, which would be seen from the enforcement of the order by ensuring the promise made as regards the distribution of palliatives is fulfilled.
Interestingly, Nigerians through radio and television interviews and analysis had held that the President's injunction was of no effect because some governors had proactively imposed partial and total lockdown in their states, and like the federal government, shut down all tertiary institutions, primary and secondary schools as a quick response to containing the virus from spreading. For instance, the Governor of Lagos State, Babajide Sanwo-Olu, had on the March 26, 2020, ordered a partial lockdown of court sittings, markets and stores, except for essential markets. Below was the governor's speech as transcribed from a video shared by CNBC AFRICA:

"...The organised private sector are to encourage their workers to be able to work from home; banks and other financial institutions are encouraged to priorities online channels for their services to the public with only essential key staff being in the office during this time. The Chief Judge of Lagos State has also been directed to ensure that all magistrate and high courts are closed immediately to public and to suspend all court sittings as much as possible, only essential services should be transacted electronically. All public parks including those in private and residential estates-swimming pools, gyms, workout stations in all public places, are expected to shutdown at this time until further notice. All markets and stores, except markets that are selling food items, water, medicines, pharmacies, medical equipment and related essential life saving products, daily life products, are hereby directed to close, effective from Thursday, 26 th $^{\text {th }}$ arch, 2020...". ${ }^{13}$

A number of states came up with similar injunctions. Governor Nyesom Wike of Rivers State closed all land borders and announced restriction of flights into and out from the state. Although the latter (flight restrictions) became an issue of discourse on traditional and social media as it was a matter of whether or not a state governor had the powers to take such a step, when it was supposed to be within the purview of the Federal Ministry of Aviation.

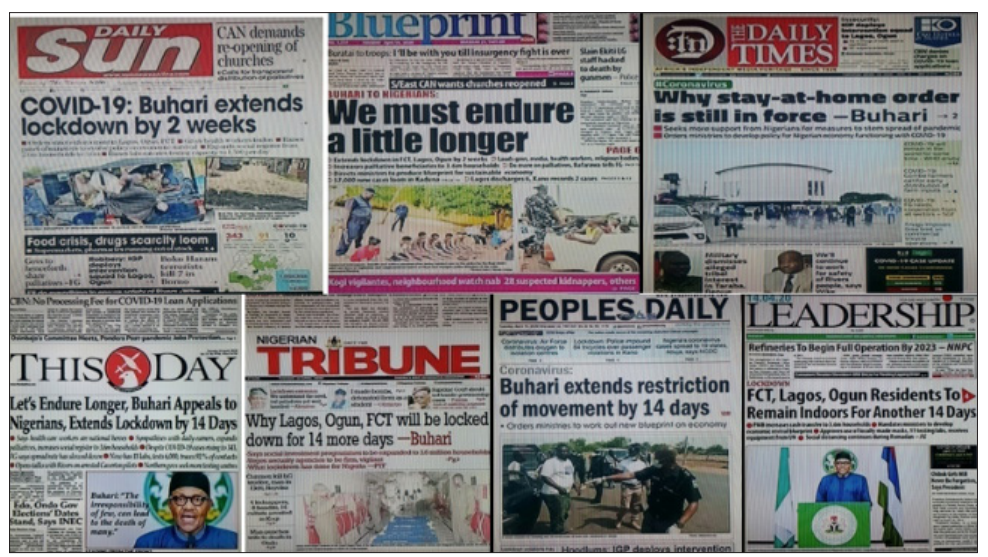

Figure 5.Lock down extension reporting by various New paper (The Daily Sun, Blueprint, The Daily Times, This Day, Nigerian Tribune, Peoples Daily and Leadership newpapers) 
The governor went on to announce total lockdown; even major markets were closed down. The media went agog as they reported Governor Wike's move to enforce his pronouncement on flights restriction when he, on April 7, 2020, stormed the office of Caverton Helicopters, and ordered the arrest of the two pilots and ten passengers on board, who flew into Rivers State from Lagos State, which was in violation of his no-movement/border closure injunction. However, the two pilots and ten passengers were granted bail on April 14, 2020 by a Port Harcourt Magistrate court. This was how it was captured on Sahara Reporters:

“...Chief Magistrate D.D. Ihua-Maduenyi of a Port Harcourt Magistrate Court has released on bail the two arrested pilots of Caverton Helicopters. The magistrate granted the pilots-Samuel Ugorji and Samuel Buhari-bail after hearing their application by their counsel. The ten passengers on board were also granted bail. The court ruled that they must provide a surety, who must be a management staff of Caverton Helicopters...must sign a bail bond of N1million... ". ${ }^{14}$

\section{Compliance with and Violation of Lockdown}

The level of compliance is relative as captured on Figure 6; in some states, citizens seemed to have complied with the lockdown when the injunction was initially given, but the story would change days after the pronouncement as the need for food and survival became very pressing. The Ogun state Commissioner of Police, Kenneth Ebrinson, after leading other security chiefs to monitor the lockdown, confirmed and lauded Ogun state residents for their civility. Dimeji KayodeAdedeji, reporting for Premium Times quoted the CP thus:

"I want to mostly thank the citizens of Ogun State for showing their sense of being civil, their sense of (being) law abiding. They have lessened the burden of the security agencies. I am here with the director of SSS, commandant of the civil defense and other security organisations...So I am happy that they have collaborated with us without allowing us to go after any of them. The compliance level - I am pleased and satisfied with it ". ${ }^{15}$
But, just as it was captured on the front page of "The Blueprint" newspaper of Friday, April 17, 2020, "Abuja residents defy lockdown order" (Figure 6), people in Abuja, the federal capital territory, which as of the time of writing this paper had recorded about eighteen cases and counting, were seen going about their businesses, without maintaining social distancing. Travellers from the neighbouring state of Nasarawa were still trooping in and out of the city. This, on the one hand, only showed that the people were careless about the severity of the pandemic because they had to look for their daily bread. On the other hand, the government and the agencies responsible for enforcing the order were not on top of their game.

Oladimeji Ramon reported that the Ajia Balogun Olubadan of Ibadanland, Oloye Adegboyega Adegoke had spoken to The Punch newspaper saying it was unrealistic to ask Nigerians to stay at home when they are hungry. Adegoke said:

"The people who are hungry cannot stay at home. That is why it is difficult to enforce the stay-at-home order. If government fails to give palliatives to people, they will not stay at home, but if they are given what they will use to stay at home, they will comply". ${ }^{16}$

Nevertheless, obeying government's order of containing the coronavirus was not only about hungry Nigerians as top Nigerian actress, Funke Akindele-Bello and her husband, Abdulrasheed Bello, became the talking point on the media owing to their violation of the directive of the Lagos State government. They were arrested by the Lagos state police command, the Attorney General of Lagos State, Moyosore Onigbanjo filed a charge and arraigned them before a magistrate court in Ogba, Lagos for violating the restriction of social and religious gatherings directive by the government. Ghaniyah Olowoyo reported that "Akindele and her husband pleaded guilty to the charge read to them. They pleaded guilty to breaching the Lagos infectious diseases regulation (2020), which prescribes N100, 000 fine or a month jail time for violators". ${ }^{17}$
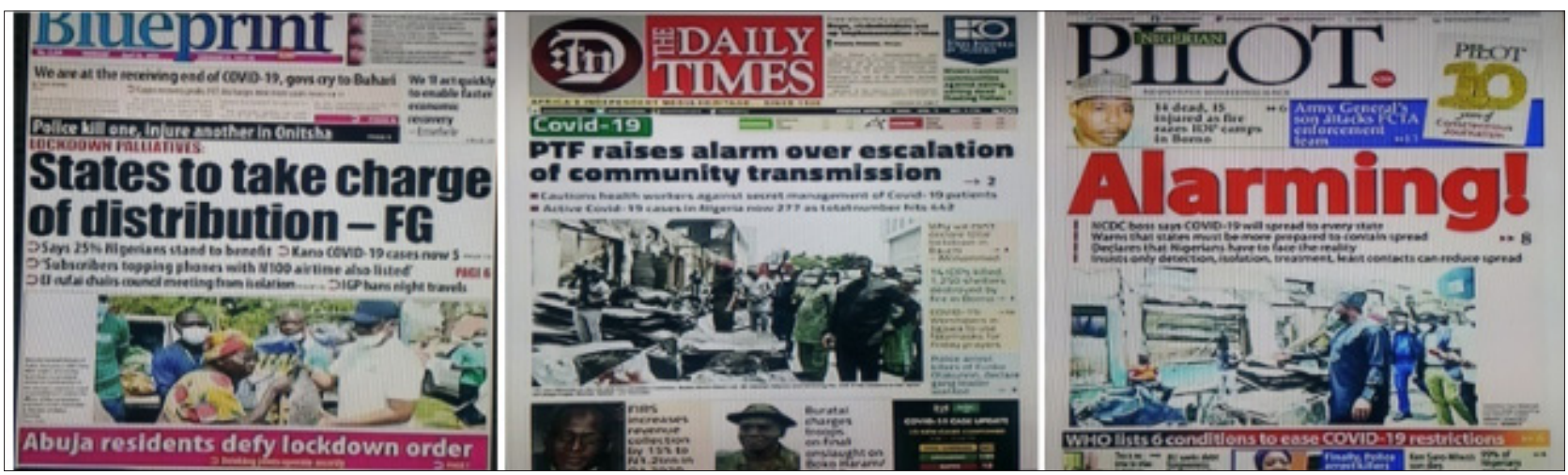

Figure 6.The Blueprint, The Daily Times, Nigerian Pilot newspapers, on compliance with lockdown 
Ironically, there was an outcry of inequity of justice on the media after Akindele and her husband were charged. This was due to the subsequent pictures that surfaced on the social media that the Attorney General of Lagos State who had charged them was also seen violating the same order he was upholding as he failed to maintain social distancing when a number of people that surpassed what caused Akindele and her husband the charge, clustered around him as he granted the media interview.

Furthermore, in trying to enforce compliance to his lockdown order, Channels TV reported how the governor of Rivers State, Nyesom Wike, on Friday, April 17, 2020, announced the arrest of twenty-two workers of Exxon Mobil. According to the Governor as published by Soonest Nathaniel:

"Security agencies arrested 22 staff of Exxon Mobil who came into the state from neighbouring Akwa Ibom State in violation of the extant Executive Order restricting movement into the state. We do not know the coronavirus status of these individuals...As a responsive government, we have quarantined them in line with the relevant health protocols and they will be charged to court". 18

Experts who were given opportunity to speak on traditional media platforms and citizen journalists who thrive on the social media have all advocated for massive testing of citizens to determine the actual number of people that may have been infected with the virus. This was because the non compliance to the lockdown order by citizens seeking for their daily livelihoods as reported by the media had led to the Presidential Task Force (PTF) on Covid-19 to raise an "alarm over escalation of community transmission" of the virus as reported by "The Daily Times" (Figure 6).

Leon Usigbe of Nigerian Tribune reported that the chairman of the Presidential Task Force (PTF) on COVID-19, and Secretary to Government of the Federation (SGF), Mr. Boss Mustapha had reacted thus:

"Initial feedback is that there is substantial compliance but, however, there are violations of those restrictions by citizens that we desire to protect. Let me emphasise that the decision to lockdown is to prevent community spread which might be dangerous to manage ${ }^{\prime \prime}{ }^{19}$

This brings to mind the issue of government providing palliatives for the people as they hope to obey the stayat-home order.

\section{Palliatives for the People}

Since people were asked to stay at home, it became necessary that they were provided with palliatives such as food and money for them to be able to cope with the stay-athome injunction. In giving attention to it, Oladimeji Ramon of Punch Newspaper reported that Oloye Adegboyega
Adegoke, the Ajia Balogun Olubadan of Ibadanland had said:

"We need to stop the spread of coronavirus. That is why it is compulsory to give palliatives to the people before we can stop them from going out". 16

The federal government, thus, in evolving strategies for the lockdown implementation, and to cushion the effect of the stay-at-home order by providing palliatives for the people, announced on March 31, 2020, that about eleven million Nigerians would benefit from the federal government.

On how these palliatives would be disbursed, the Minister of Humanitarian Affairs, Disaster Management and Social Development, Mrs. Sadiya Umar Farouk, claimed that government already had a social register of those considered as the vulnerable in society in 35 states of the federation; they belonged to around 2.6 million households across the country. ${ }^{19}$

As the media continued in setting the agenda on how these palliatives would get to the people, Central Bank of Nigeria revealed on Friday, April 17, 2020 that monetary donations were made by them and the private sector under the auspices of Private Sector Coalition Against COVID-19 (CACOVID) had amounted to 25.8 billion naira. One hundred and seven (107) donors, made up of individuals, banks and other corporate bodies came to the party. ${ }^{20}$

Following donations made by the private sector and the commitment by government was the question of how the funds had been used: did the relief funds get to the people as intended? Was the disbursement fairly carried out? Did every region get the palliatives? Was there equity in the process? Were the funds accounted for?

Sequel to these questions, Kelvin Ebiri and Ann Godwin of The Guardian newspaper reported that the federal government was faulted for being selective and excluding some regions of the country in their interventions. ${ }^{21}$ This was observed by some Civil Society groups including Civil Liberty Organisation (CLO), Social Action, and Media COVID-19 Situation Room, who alleged that the Niger Delta states were excluded by the Federal Government, especially in the distribution of test kits, relief materials and establishment of isolation centres. The Chairman (South South zone), Civil Liberties Organisation (CLO), Stevyn Obodoekwe, and chairperson of Social Action, Vivian Bellonwu reacted to government's responses to the COVID-19 pandemic in Nigeria:

"We have observed, with dismay, that in the disbursement of the funds, the federal government has, as usual, excluded the Niger Delta and other Southern States. We have seen nepotism and political bias at play in the course of the distribution of the palliatives, including cash transfers by the federal government. We have received disquieting reports of marginalization and exclusion of the Niger Delta 
states in selective distribution of test kits and the building of isolation centres". ${ }^{21}$

It is noteworthy that the federal government's decision to disburse palliatives did not in any way stop states to make efforts in raising funds for the course. But, the complaint at the end of the day was inadequacy of the palliatives to ensure sustenance throughout the period of lockdown; thus, Nigerians were forced to defy the injunction to go about their daily businesses. Throughout the duration of this paper, the problem of palliatives remained a big and unresolved issue.

\section{The Frontliners}

The media was awash on Friday, April 24, 2020, with the concern expressed by the Nigeria health minister, Dr. Osagie Ehanire, who announced that forty health workers had tested positive to covid-19 as illustrated in (Figure 7). He said:

"This warning has become necessary due to the number of health workers who have tested positive for COVID-19. They are over 40 now. Apart from the over 40 health workers, there are others who have been quarantined in the last two weeks due to exposure and have not been able to contribute to efforts of the health sector".22
(NARD), Dr. Aliyu Sokomba did mention this and further emphasised the need for health workers to be motivated by reviewing their hazard allowance and providing them with life insurance. ${ }^{22}$ The Chief Executive Officer of the Institute of Human Virology, Nigeria (IHVH), Dr Patrick Dakum and the President of Nigerian Medical Association, (NMA), Dr. Francis Faduyile, both maintained that PPEs were largely unavailable and efforts be made for masks, gloves, gowns, eye shields, to be adequate so that used ones are disposed and not reused. ${ }^{22}$ On the other hand, there is the notion that health workers might not have been vigilant enough whilst managing patients, thus, the increase in infections. Nigeria's minister of health said:

"Frontline health workers must undertake refresher courses on Infection, Prevention and Control (IPC) at interval... Remain vigilant in the line of duty and maintain a high index of suspicion for COVID-19". 22

Nevertheless, and fundamentally, the media have been up and doing in their reportage, and there is no doubt that if the battle against COVID-19 must be won, the media's role can never be underestimated. The media, indeed, have not left any stone unturned since the outbreak of this deadly virus.

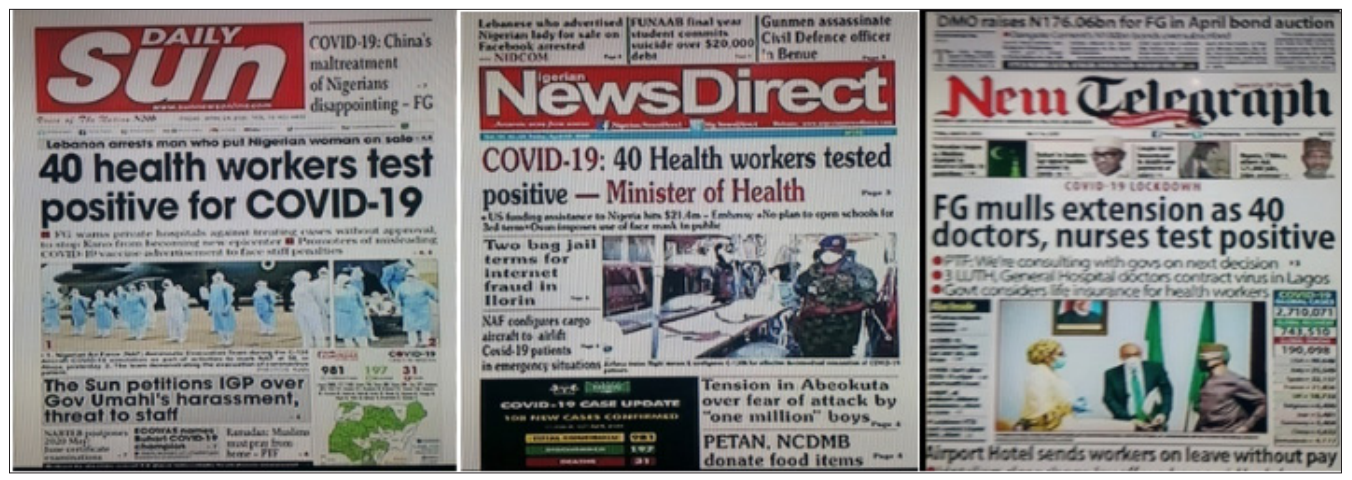

Figure 7.Daily Sun, Nigeria News Direct and New Telegraph, on health workers testing positive for covid-19

However, it wasn't completely surprising that Nigerian frontliners also got infected as the Director General of World Health Organisation, WHO, Tedros Ghebreyesus, on April 6, 2020 announced that about 3000 health workers comprising doctors, nurses, laboratory scientists, had tested positive for the virus the world over. ${ }^{23}$ But, that was just a tip of the iceberg as Italy's ministry of Health revealed that over 4,500 health workers were infected and about 400 lost their lives to the virus. ${ }^{23}$

On the one hand, some respondents disclosed that health workers were not being provided with adequate and safe Personal Protective Equipment (PPE) to carry out their jobs. Daily Trust reporters, Ojoma Akor and Abbas Jimoh reported that the President of Nigeria Association of Resident Doctors

\section{Conclusion and Going Forward}

This study carefully evaluated the distribution and responses of the Nigerian media to the COVID-19 pandemic in Nigeria in the first 2 months of confirmation, using data collected from the websites of the Nigeria Centre for Disease Control, NCDC and Worldometer. Economic activities of the country were destabilised with the outbreak of the coronavirus pandemic in Nigeria. The government of Nigeria took desperate steps to contain the spread of the virus, among which were the pronouncement of lockdowns and the giving of palliatives to citizens to cushion the effect of the stay-athome order. But the media recounted that the injunctions were not totally adhered to as the issue of hunger became a matter of serious concern. Unfortunately, with all the 
commitment from government, donations from individuals and the private sector to the COVID-19 relief fund, the socalled palliatives were either not seen or not adequate to sustain even the few beneficiaries for the period of the lockdown; thus, resulting in citizens defying the order and resuming their means of survival, leading to possible community transmission of the disease. There was also the issue of healthcare workers lacking adequate protective equipment and motivation to carry out their frontline responsibilities. Some of the frontliners tested positive for the virus and few died. While Lagos was the epicentre of the disease in Nigeria, the case of Kano became a concern as the disease spread with lightning speed after the first cases were recorded. As of April 30, 2020, the progression of transmission/infection (based on geographical regions) was highest in the South West region, and lowest in the South East. The paper showed that, approximately, 80\% transmission was mainly through contact and incomplete epidemiological links, which clearly indicated one thing: community transmission. Having effectively responded to the disease, by bringing to the knowledge of citizens the war against the virus and exposing the vulnerability of the country, the Nigerian media (traditional and new) condemned the government to evolve strategies, policies, and regulations that would ensure that the disease is contained, as it were. Going forward, in order to stem the COVID-19 pandemic, effective and aggressive contact tracing, community (house-to-house) testing, isolation and treatment are the near answers for a serious minded country that hopes to win the war.

\section{Conflict of Interest: None}

\section{References}

1. Ohimain El. How the Spread of Ebola Virus was Curtailed in Nigeria. International Journal of Medical and Pharmaceutical Case Reports 2015; 4(1): 11-20.

2. Bassey SE,Izah SC. Some determinant factors of Malaria Prevalence in Nigeria. Journal of Mosquito Research 2017; 7(7): 48-58.

3. Bassey SE, Izah SC. Nigerian plants with insecticidal potentials against various stages of mosquito development. ASIO Journal of Medical and Health Sciences Research 2017; 2(1): 07-18.

4. Worldometer (2020). https://www.worldometers.info/ coronavirus/). (Accessed April 13, 2020).

5. Nigerian Centre Disease Control (2020). An update of COVID-19 outbreak in Nigeria. https://ncdc. gov.ng/diseases/sitreps/?cat=14\&name $=$ An $\% 20$ update\%20of\%20COVID-19\%20outbreak\%20in\%20 Nigeria(Accessed May 1, 2020).
6. Cheng VCC, Lau SKP, Woo PCY, Yuen KY. Severe Acute Respiratory Syndrome Coronavirus as an Agent of Emerging and Reemerging Infection. Clinical Microbiology Reviews 2007; 20(4): 660-694.

7. Nature (2020). Coronavirus disease officially named COVID-19. https://www.nature.com/articles/d41586020-00154-w.(Accessed March 26, 2020).

8. Ndimele O-M,Kasarachi I. Fundamental of Mass Communication. Port Harcourt: M.J. Grand Orbit Communications Ltd. 2007.

9. Baran SJ, Davis DK. Theories of Mass Communication. California: Mayfield Publishing Company. 1995.

10. Mcquail D.Media and Democracy in a Multi-Plural Nigeria in Agabu, V. and Nwabueze, C. (eds) 2008. Readings in Mass Communication: Global Perspectives on Communication Issues. Owerri: Top Shelve Publishers. 1987.

11. Daramola I . Introduction to Mass Communication. $2^{\text {nd }}$ Edition. Lagos: Rotham Press Ltd. 2003.

12. Business Day (April 13, 2020).Full Speech of President Muhammadu Buhari: https://businessday.ng/leadstory/article/full-speech-of-president-muhammadubuhari/amp/ (Accessed April 14, 2020).

13. CNBC AFRICA(March 25, 2020).COVID-19: Lagos to begin partial 7-day shutdown: https://www.cnbcafrica. com/west-africa/2020/03/25/covid-19-lagos-to-beginpartial-7-day-shutdown/ (Accessed April 16, 2020).

14. Sahara Reporters(April 14, 2020). Court Grants N1m Bail To Caverton Helicopter Pilots: https:(//saharareporters. com/2020/04/14/court-grants-n1m-bail-cavertonhelicopter-pilots (Accessed April 18, 2020).

15. Premium Times(April 4, 2020).Lockdown: Ogun records maximum compliance on day onehttps://www. premiumtimesng.com/regional/ssouth-west/385996lockdown-ogun-records-maximum-compliance-on-dayone.html(Accessed April 18, 2020).

16. Punch Newspaper (April 22, 2020).Obeying lockdown difficult for hungry peoplehttps://punchng.com/ obeying-lockdown-difficult-for-hungry-peopleadegoke/ (Accessed April 22, 2020).

17. Premium Times. FunkeAkindele, husband plead guilty in court for violating coronavirus lockdown: https:// www.premiumtimesng.com/news/headlines/386215breaking-funke-akindele-husband-plead-guilty-incourt-for-violating-coronavirus-lockdown.html/ (Accessed April 19.2020).

18. Channels TV.Lockdown Order: Wike Announces Arrest, Quarantine of 22 Exxon Mobil Workershttps://www. channelstv.com/2020/04/17/lockdown-order-wikeannounces-arrest-quarantine-of-22-exxon-mobil- 
workers/amp/ (Accessed April 22, 2020).

19. Nigerian Tribune(March 31, 2020).COVID-19: FG To Reach $11 \mathrm{~m}$ Nigerians With Palliatives https:// tribuneonlineng.com/covid-19-fg-to-reach-11mnigerians-with-palliatives/ (Accessed April 22, 2020).

20. Premium Times (April 17, 2020) COVID-19: Private sector relief fund now N25.8 billion - CBN: https:// www.premiumtimesng.com/coronavirus/388482covid-19-private-sector-relief-fund-now-n25-8-billioncbn.html (Accessed April 27, 2020).

21. Guardian Newspaper. CSOs accuse FG of excluding Niger Delta from COVID-19 interventionshttps://m.guardian. ng/news/csos-accuse-fg-of-excluding-niger-delta-fromcovid-19-interventions/ (Accessed April 23, 2020).

22. Daily Trust). 77 Nigerian health workers infected with COVID-19, Lassa fever: https://www.dailytrust.com. ng/77-nigerian-health-workers-infected-with-covid19-lassa-fever.html (Accessed April 28, 2020).

23. All Africa.Nigeria: Protecting Health Workers Against COVID-19 Pandemic: https://allafrica.com/ stories/202004090416.html. (Accessed April 22, 2020) . 